\title{
COMPARISON OF THE EFFECT OF FOREIGN DEBT ON ECONOMIC GROWTH OF INDONESIA IN THREE PERIODS OF GOVERNMENT
}

\author{
Endang Kusdiah Ningsih", Esty Naruliza, Asma Mario \\ Faculcy of Economics IBA University \\ endanghasan62@gmail.com
}

\begin{abstract}
This purpose of this articel is to determine the ratio of the effect of foreign debt on economic growth. Since the reign of the Old Order up to the reign of the Reform Order to date, the Indonesian government has always done debt (overseas loans). So as if the growth that accomplished by the Indonesian economy each year can not be separated from foreign debt.The data used are secondary data obtained from the Central Bureau of Statistics and Bank Indonesia. The analysis technique to be used is Quantitative Descriptive Method. The results of hypothesis test show that the effect of foreign debt on economic growth only during the Reform Order.
\end{abstract}

Keywords: Foreign Debt, Economic Growth

\section{INTRODUCTION}

\subsection{Backgrounds}

Economic growth is a process of increasing the production capacity of an economy that can be measured through an increase in national income. With the growth of the economy can be indicated success in economic development.To achieve high economic development requires a large amount of capital, so many countries in the world finance economic development by overseas loans (debt), especially developing countries such as Indonesia. In the early stage of development (early stageof development), a country's foreign debt has increased because the country has no capital development. However, during the stage of development, the foreign debt of a country will decrease. In other words, there is a negative correlation between economic growth and external debt

During the Old Order (1945-1966), a newly independent Indonesia needed substantial funds to undertake development in order to improve the living standards of the people who were hurt by the Dutch colonialism. So Indonesia began to borrow (debt) from abroad. Indonesia's foreign debt amounted to USD 2.1 billion or $29 \%$ of total GDP. The debt was inherited to the new order government. In this old order period, economic growth has not shown a significant increase.During the New Order (1967-1998), foreign debts grew larger as the re-entry of Indonesia became a member of the IMF and World Bank. In addition, countries, coordinated by the Dutch government 
incorporated in IGGI, further increase Indonesia's foreign debt. However, it can not be denied that during the New Order, Indonesia achieved relatively high economic growth. In 1998, the new order had foreign debt of USD 171 billion to the next government.

The reign of the Reform Order (1998-2014), consisted of several periods of leadership, namely:

1. The transition period of $\mathrm{BJ}$ Habibie, accumulated additional foreign debt of Indonesia up to USD 20 billion, the total foreign debt of Habibie period inherited to the next government was USD 178 billion

2. The period of Abdulrahman Wahid, had reduced Indonesia's foreign debt amounted USD 21.1 become USD 157 billion, But at the end of leadership, Gus Dur had foreign debt become 1,273.18 trillion Rupiahs to the next government.

3. The period of Megawati, the amount of debt Indonesia has decreased to Rp. $1,225.15$ trillion by way of the sale of state assets. And at the end of the term of office, Megawati foreign debt of 1,299.5 trillion Rupiahs

4. The tenure of SBY,

Indonesia's foreign debt from the IMF has been settled.

However, at the end of the reign, SBY foreign the debt of .2.023 triliion Rupiahs to the next government

The increase in foreign debt during this reformation period has not been accompanied by an increase in the continuous growth of economists, The purpose of this research to determine "The Effect of Foreign Debt on
Indonesian Economic Growth in Three Periods of Goverment

Hypothesis in this research are 1) Suspected there was an influence of foreign debt on economic growth during the Old Order. 2) Suspected there was an influence of foreign debt on economic growth during the New Order period. 3). Suspected there was an influence of foreign debt on economic growth during the Reform Order

\section{LITERATURE REVIEW}

\subsection{Foreign Debt}

\subsubsection{Definition and Causes}

According to Bank Indonesia, the position of Indonesia's Foreign Debt (ULN) is based the actual obligations of the Indonesian population to nonresidents at a time, excluding contingent, requiring interest and / or principal repayment in the future

Broadly speaking, foreign debt is grouped into 2 , that is

1. Government Overseas Debt That is debt held by the central government, consisting of bilateral / multilateral debts, export credit facilities, commercial debt, and leasing, as well as State Securities (issued outside and inside the country) owned by non- population.

2. Private Overseas Debt The foreign debt of the population (other than the government and central bank) was non-residents in foreign currency and rupiah based on the loan agreements or other agreements, deposits and other obligations. Included in the component of private foreign debt is the obligation in form of debt securities issued in the country and owned by nonresidents. The private sector includes banks and non-banks. 
Private non-bank consists of Non-Bank Financial Institutions and non-financial companies, as well as individuals.

\subsubsection{Causes of Foreign Debt}

The foreign debt crisis began in the 1980s, and the experienced not only by developed countries but also by developing countries. The causes of the foreign debt crisis are: (Tambunan, 2012)

1. The current account deficit exceeds the current account surplus, resulting in reduced foreign exchange reserves. The state will make loans or foreign debt . to cover the cost of importing capital goods and the needs of domestic production activities.

2. The funds needed for investment exceeds the funds available in the country or in other words the amount of investment is greater than the savings of the community (investment-saving gap)

3. High inflation rate

4. Structural inefficient in the economy

\subsection{Economic Growth}

Economic growth is defined as a long-term increase in each capita output. There are three aspects that need to be considered in the definition, namely: (1) process, (2) output per capita, and (3) long term. Economic growth is a process, not an economic picture at a time.

Simon Kuznet (in SadonoSukirno 2012) defines the economic growth of a country as "the country's ability to provide an ever-increasing economic goods for its inhabitants, the growth of this capability based on technological and institutional advancement and the ideological adjustment it needs."

\subsection{Conceptual Framwork}
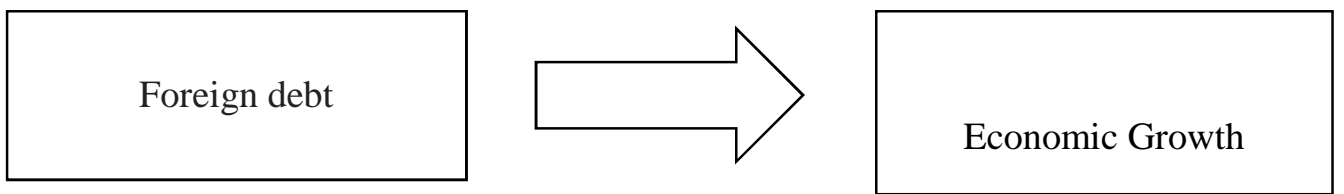

Figure 1 explains the relatioship between Foreign Debt on Economic Growth

Source : Processed (2016)

\section{Research Method}

\subsection{Research Site}

The research location is where researchers collect data. Therefore, this research is conducted at the Central Bureau of Statistics and Bank Indonesia, where both places provide data that researchers needed.

\subsection{Method Used and Data Analysis Technique}


The method used in this study is a quantitative method by using data in the form of numbers to analyze how big the influence of foreign debt on economic growth

There are several steps used in this method:

1. Perform normality test data .The data is normally distributed or not The statistical test used for the normality test in this study is the normality test of the kolmogorovsmirnov method. If the table kolmogorofsmirnov (KS)> 0.05 then the residual is normally distributed.

2. Perform F Test where:

a. If $\mathrm{F}$ arithmetic ( $\mathrm{F}$ on output) $>\mathrm{F}$ table, $\mathrm{H} 0$ is rejected.

b. If $\mathrm{F}$ arithmetic (number $\mathrm{F}$ at

\author{
output) $<\mathrm{F}$ table, $\mathrm{H} 0$ is \\ accepted
}

3. Determining a mathematical method to reflects a causal relationship between variables depends on independent variables

4. Simple regression

In this research, a simple linear regression model is formulated as follows

$Y=a+b X+e$

Where :

$\mathrm{Y}=$ Economic Growth

$\mathrm{X}=$ Foreign Debt

$\mathrm{e}=$ error

$\mathrm{a}=$ Constanta

$\mathrm{b}=$ Regression Coefficient

\section{RESULTS AND DISCUSSION}

\subsection{The Effect of Foreign Debt on Economic Growth in Old Order Period \\ 1. Normality Test}

Table 1

Normality Test

One-Sample Kolmogorov-Smirnov Test

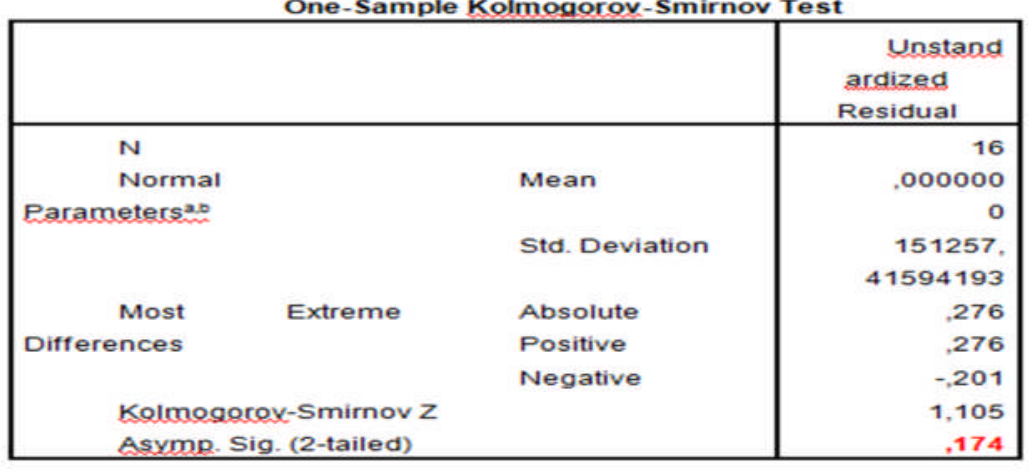

From Table 1, it is known that the value of Kolmogorov-Smirnov is 1.105. Asymp value. Sig. (2-tailed) on the Kolmogorov-Smirnov OneSample Test table is greater than 0.05 $(0.174>0.05)$. It can be deduced that

\section{the residuals are normally distributed.}

2. Descriptive statistics

Descriptive statistics is an analysis that is used to provide an explanation or description of an observed data 
Table 2

Descriptive Statistics

\begin{tabular}{|l|r|r|r|r|r|}
\hline & \multicolumn{1}{|r|}{ N } & Minimum & Maximum & Mean & Std. Deviation \\
\hline FD(miliar US\$) & 16 & 218,10 & 103067,00 & $\mathbf{3 9 9 0 4 , 8 1 8 8}$ & 45048,92840 \\
PDB (miliarRp) & 16 & 100000,00 & 685375,02 & $\mathbf{3 1 9 6 9 6 , 0 8 8 1}$ & 217014,55192 \\
Valid N (listwise) & 16 & & & & \\
\hline
\end{tabular}

Considering the table 4.1.2., it is known that the average for Foregign Debt (ULN) (billion US \$) for 16 years from
1951 to 1966 amounted to 39904,819 . While the GDP (billion Rp) has an average of 319696,088 .

\section{Correlation Test}

Table 3

Correlations

\begin{tabular}{|ll|r|r|}
\hline & & FD (miliar US\$) & \multicolumn{2}{l|}{$\begin{array}{l}\text { PDB } \\
\text { (miliarRp) }\end{array}$} \\
\hline FD (miliar US\$) & Pearson Correlation & 1 &, $717^{* *}$ \\
& Sig. (2-tailed) & 16 &, $\mathbf{0 0 2}$ \\
& $\mathrm{N}$ &, $717^{* *}$ & 16 \\
\hline PDB (miliarRp) & Pearson Correlation &, 002 & 16 \\
& Sig. (2-tailed) & 16 & 16 \\
& $\mathrm{~N}$ & & \\
& & & 16 \\
\hline
\end{tabular}

**. Correlation is significant at the 0.01 level (2-tailed).

According to the above table, it is known that the probability value (Sig.) Is 0.002 which is smaller than 0.05 then it can be drawn a conclusion that there is a relationship between the variable of foreign debt with the gross dosmetic product 


\section{Regression Test}

Table 4

ANOVA ${ }^{b}$

\begin{tabular}{|ll|l|l|l|l|l|}
\hline \multicolumn{2}{|l|}{ Model } & Sum of Squares & Df & Mean Square & F & Sig. \\
\hline 1 & Regression & $3,632 \mathrm{E} 11$ & 1 & $3,632 \mathrm{E} 11$ & $\mathbf{1 4 , 8 1 9}$ & $\mathbf{, 0 0 2}^{\mathbf{a}}$ \\
& Residual & $3,432 \mathrm{E} 11$ & 14 & $2,451 \mathrm{E} 10$ & & \\
& Total & $7,064 \mathrm{E} 11$ & 15 & & & \\
\end{tabular}

a. Predictors: (Constant), FD (miliar US\$)

b. Dependent Variable: GDP (miliarRp)

The result of Regression test is show that $\mathrm{F}$ arithmetic is $14.819>4.600(\mathrm{~F}$ table). It means can that there is significant influence of Foreign Debt on Gross Domestic Product. The result of this research is consistent with the result of research conducted by Rahman (2017).

\section{Summary Model}

Table.4.1.5.

Model Summary ${ }^{b}$

\begin{tabular}{|l|l|l|l|l|l|}
\hline Model & R & R Square & $\begin{array}{l}\text { Adjusted } \\
\text { Square }\end{array}$ & $\begin{array}{l}\text { Std. Error of the } \\
\text { Estimate }\end{array}$ \\
\hline 1 & $\mathbf{7 1 7}$ &, $\mathbf{5 1 4}$ &, 480 & 156566,30000 \\
\hline
\end{tabular}

a. Predictors: (Constant), FD (miliar US\$)

b. Dependent Variable: GDP (miliarRp)

\section{Correlation}

Based on the summary model table 4.1.5. in column $\mathrm{R}$ it is known that the value of $\mathrm{R}$ is 0.717 or has a strong level of closeness (Sugiyono, 2010).

Based on the summary model table in the R Square column it is known that the
$\mathrm{R}$ Square value is 0.514 or $51.4 \%$ the ability of Foreign Debt to explain or affect the Gross Domestic Product in Indonesia. And the rest of $48.6 \%$ is explained or influenced by other variables is not observed in this observation. 
Economics and Accounting Journal

Vol. 1, No. 3, September 2018

6. Mathematical Model

\begin{tabular}{|c|c|c|c|c|c|}
\hline \multirow[b]{2}{*}{ Model } & \multicolumn{2}{|c|}{ Unstandardized Coefficients } & \multirow{2}{*}{$\begin{array}{l}\text { Standardized } \\
\text { Coefficients } \\
\text { Beta }\end{array}$} & \multirow[b]{2}{*}{$\mathrm{T}$} & \multirow[b]{2}{*}{ Sig. } \\
\hline & $\mathrm{B}$ & Std. Error & & & \\
\hline $\begin{array}{l}\text { Table } 6 \text { (Constant) } \\
\text { FD (miliar US\$) }\end{array}$ & $\begin{array}{l}181849,299 \\
3,454\end{array}$ & $\begin{array}{l}53050,498 \\
, 897\end{array}$ & ,717 & $\begin{array}{l}3,428 \\
3,849\end{array}$ & $\begin{array}{l}, 004 \\
, 002\end{array}$ \\
\hline 1 & & & & & \\
\hline
\end{tabular}

a. Dependent Variable: GDP (miliarRp)

Based on the above table, it can be seen that the mathematical model is formed is as follows:

$$
\begin{aligned}
& Y=a+b X \\
& Y=\mathbf{1 8 1 . 8 4 9 , 2 9 9 + 3 , 4 5 4 X}
\end{aligned}
$$

\subsection{The Effect of Foreign Debt on Indonesia's Economic Growth in the New Order Period}

\section{Normality Test}

Table 7

One-Sample Kolmogorov-Smirnov Test

\begin{tabular}{|ll|l|}
\hline & & $\begin{array}{l}\text { Unstandardized } \\
\text { Residual }\end{array}$ \\
\hline N & & 32 \\
& &, 0000000 \\
& Std. Deviation & 1275374,97002 \\
Most Extreme Differences & Absolute & 230 \\
& Positive &, 247 \\
& Negative &, 247 \\
Kolmogorov-Smirnov Z & &,- 167 \\
Asymp. Sig. (2-tailed) & & 1,397 \\
& &, 040 \\
\hline
\end{tabular}


Economics and Accounting Journal

Vol. 1, No. 3, September 2018

One-Sample Kolmogorov-Smirnov Test

\begin{tabular}{|ll|l|}
\hline & & $\begin{array}{l}\text { Unstandardized } \\
\text { Residual }\end{array}$ \\
\hline Normal Parameters & & 32 \\
& Mean &, 0000000 \\
& Std. Deviation & 1275374,97002 \\
Most Extreme Differences & Absolute & 230 \\
& Positive &, 247 \\
Kolmogorov-Smirnov Z & &, 247 \\
Asymp. Sig. (2-tailed) & &,- 167 \\
\end{tabular}

a. Test distribution is Normal.

b. Calculated from data.

Based on the normality test, it is known that the value of Kolmogorov-Smirnov is 1.397. Asymp value. Sig. (2-tailed) on the One-Sample Kolmogorov-Smirnov
Test table is smaller than 0.05 (0.04> 0.05). It can be deduced that the residuals are not normally distributed.

\section{Descriptive Statistitics}

Table 8

Descriptive Statistics

\begin{tabular}{|l|l|l|l|l|l|}
\hline & N & Minimum & Maximum & Mean & Std. Deviation \\
\hline FD (miliar US\$) & 32 & 2076,00 & 30609,00 & $\mathbf{7 3 6 1 , 5 9 3 8}$ & 6115,36824 \\
PDB (miliarRp) & 32 & 685375,02 & 5356003,34 & $\mathbf{1 7 5 6 3 9 1 , 4 2 9 7}$ & 1335887,70317 \\
Valid N (listwise) & 32 & & & & \\
\hline
\end{tabular}

According to the above table, it is known that the average for $\mathrm{ED}$ (billions of US \$) for 32 years from
1967 to 1998 is amounted to 7361,594. While GDP (billion Rp) has an average of 1756391,430 . 


\section{Correlation Test}

Table 9

Correlations

\begin{tabular}{|ll|l|l|}
\hline & & FD (miliar US\$) & PDB (miliarRp) \\
\hline FD (miliar US\$) & Pearson Correlation & 1 &, 298 \\
& Sig. (2-tailed) & &, 098 \\
& N & 32 & 32 \\
\hline PDB (miliarRp) & Pearson Correlation &, 298 & 1 \\
& Sig. (2-tailed) &, 098 & 32 \\
& N & 32 & \\
\hline
\end{tabular}

According to the above table, it is known that the probability value (Sig.) Is 0.098 which is larger than 0.05 it can be drawn a conclusion that there is no relationship between the variable of foreign debt with gross dosmetic product

\section{Regression Test}

Table 10

ANOVA ${ }^{b}$

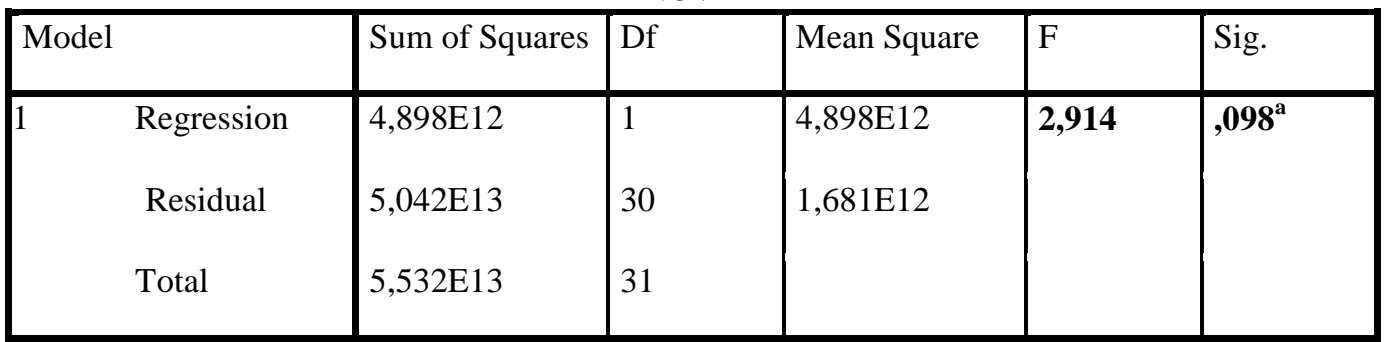

a. Predictors: (Constant), ULN (miliar US\$)

b. Dependent Variable: PDB (miliarRp)

The result of Regression test is show that $\mathrm{F}$ arithmetic is is 2,914 $<4.171$ (F table) It means can that there is no significant influence of Foreign Debt on Gross Domestic
Product. The result of this research is not consistent with the result of research conducted by Malik (2017). 


\section{Summary Models}

Table 11

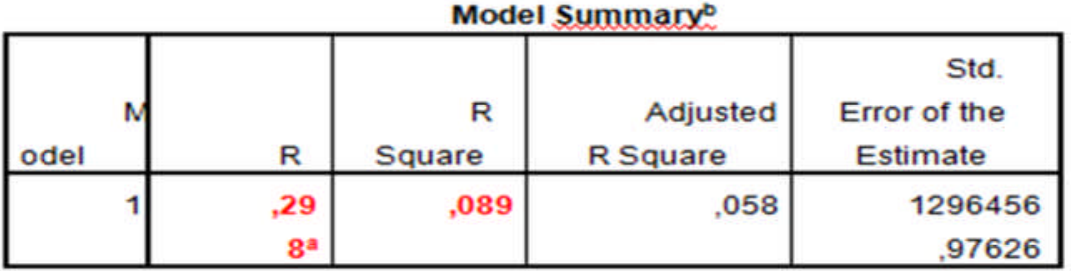

a. Predictors: (Constant), ULN (miliar US\$)

b. Dependent Variable: PDB (miliar Rp)

\section{Correlation}

Based on the summary model table in column $\mathrm{R}$ it is known that the value of $\mathrm{R}$ is 0.298 or has a low level of closeness.

\section{Regression}

Based on the summary model table in the R Square column it is known that the
$\mathrm{R}$ Square value is 0.089 or $8.9 \%$ the ability of Foreign Debt to explain or affect the Gross Domestic Product in Indonesia. And the rest of $91.1 \%$ is explained or influenced by other variables is not observed in this observation

\section{Mathematical Model}

Table 12

Coefficients $^{a}$

\begin{tabular}{|c|c|c|c|c|c|}
\hline \multirow[b]{2}{*}{ Model } & \multicolumn{2}{|c|}{ Unstandardized Coefficients } & \multirow{2}{*}{\begin{tabular}{|l|}
$\begin{array}{l}\text { Standardized } \\
\text { Coefficients }\end{array}$ \\
Beta
\end{tabular}} & \multirow[b]{2}{*}{$\mathrm{T}$} & \multirow[b]{2}{*}{ Sig. } \\
\hline & B & Std. Error & & & \\
\hline $\begin{array}{l}\text { (Constant) } \\
\text { PDB (miliar US\$) }\end{array}$ & $\begin{array}{l}1277873,849 \\
65,002\end{array}$ & $\begin{array}{l}362069,525 \\
38,076\end{array}$ & 298 & $\begin{array}{l}3,529 \\
1,707\end{array}$ & $\begin{array}{l}, 001 \\
, 098\end{array}$ \\
\hline
\end{tabular}

a. Dependent Variable: PDB (miliarRp)

Based on the above table, it can be seen that the mathematical model is formed as follows:

$$
\begin{aligned}
& Y=a+b X \\
& \quad Y=1.277 .873,849+65,002 X
\end{aligned}
$$


4.3. The Effect of Foreign Debt on Indonesia's Economic Growth in the Reform Order Period

1. Normality Test

Table 13

One-Sample Kolmogorov-Smirnov Test

\begin{tabular}{|ll|l|}
\hline & & $\begin{array}{l}\text { Unstandardized } \\
\text { Residual }\end{array}$ \\
Normal Parameters ${ }^{\mathrm{a}, \mathrm{b}}$ & Mean & 16 \\
& Std. Deviation &, 0000000 \\
& & 1475682,55105 \\
Most Extreme Differences & Absolute & 655 \\
& Positive &, 217 \\
Kolmogorov-Smirnov Z & &, 217 \\
Asymp. Sig. (2-tailed) & &,- 155 \\
& &, 868 \\
\hline
\end{tabular}

a. Test distribution is Normal.

b. Calculated from data.

Based on the normality test, it is known that the value of KolmogorovSmirnov is 0.955 . Asymp value. Sig. (2tailed) on the Kolmogorov-Smirnov
One-Sample Test table is greater than 0.05 (0.438> 0.05). Thus it can be deduced that the residuals are normally distributed

\section{Descriptive Statistics}

Table 14

Descriptive Statistics

\begin{tabular}{|l|l|l|l|}
\hline & Mean & Std. Deviation & N \\
\hline Y & $\mathbf{4 5 1 4 9 1 8 , 4 5 5 6}$ & 2966647,99082 & 16 \\
$\mathrm{X}$ & $\mathbf{1 6 1 7 7 9 , 0 6 7 5}$ & 55251,52184 & 16 \\
\hline
\end{tabular}

According to the above table, it is known that the average for Indonesia's economic growth for 16 years from
1999 to 2014 amounted to 4514918,455 . While foreign debt has an average of 161779.067 . 


\section{Correlation Test}

Table. 15

Correlations

\begin{tabular}{|ll|l|l|}
\hline & & $\mathrm{X}$ & $\mathrm{Y}$ \\
\hline $\mathrm{X} \quad$ Pearson Correlation & 1 &, $868^{* *}$ \\
& Sig. (2-tailed) & &, 000 \\
$\mathrm{~N}$ & 16 & 16 \\
\hline Y & Pearson Correlation &, $868^{* *}$ & 1 \\
& Sig. (2-tailed) &, 000 & \\
$\mathrm{~N}$ & 16 & 16 \\
\hline
\end{tabular}

**. Correlation is significant at the 0.01 level (2-tailed).

With regard to the above table, it is known that the probability value (Sig.) Is 0.000 which is smaller than 0.05 it can be drawn a conclusion that there is a relationship between the variable of external debt with economic growth .

\section{Regression Test}

Table 16

ANOVA ${ }^{b}$

\begin{tabular}{|ll|l|l|l|l|l|}
\hline Model & & Sum of Squares & df & Mean Square & F & Sig. \\
\hline 1 & Regression & $9,935 \mathrm{E} 13$ & 1 & $9,935 \mathrm{E} 13$ & $\mathbf{4 2 , 5 8 1}$ & $\mathbf{, 0 0 0}^{\mathbf{a}}$ \\
& Residual & $3,266 \mathrm{E} 13$ & 14 & $2,333 \mathrm{E} 12$ & & \\
& Total & $1,320 \mathrm{E} 14$ & 15 & & & \\
\end{tabular}

a. Predictors: (Constant), $\mathrm{X}$

b. Dependent Variable: Y

The result of Regression test is show that $\mathrm{F}$ arithmetic is is $42,581>4,600$ (F table). It means can that there is no significant influence of Foreign Debt on
Gross Domestic Product. The result of this research is not consistent with the result of research conducted by Mariska (2016). 


\section{Summary Model}

Table 17

Model Summary ${ }^{b}$

\begin{tabular}{|l|l|l|l|l|l|}
\hline Model & $\mathrm{R}$ & R Square & $\begin{array}{l}\text { Adjusted } \\
\text { Square }\end{array}$ & $\begin{array}{l}\text { Std. Error of the } \\
\text { Estimate }\end{array}$ & Durbin-Watson \\
\hline 1 & $\mathbf{, 6 6 8}^{\mathbf{a}}$ & $\mathbf{, 7 5 3}$ &, 735 & 1527476,55751 &, 567 \\
\hline
\end{tabular}

a. Predictors: (Constant), $\mathrm{X}$

b. Dependent Variable: Y

\section{Correlation}

Based on the summary model table in column $\mathrm{R}$ it is known that the value of $\mathrm{R}$ is 0.868 which has a very strong level of closeness

\section{Regression}

Based on the summary model table in the R Square column it is known that the $\mathrm{R}$ Square value is 0.753 or $75.3 \%$ the ability of Foreign Debt to explain or influence the Economic Growth in Indonesia. And the rest of $24.7 \%$ is explained or influenced by other variables which is not observed in this observation

\section{Mathematical Model}

Table 18

Coefficients $^{a}$

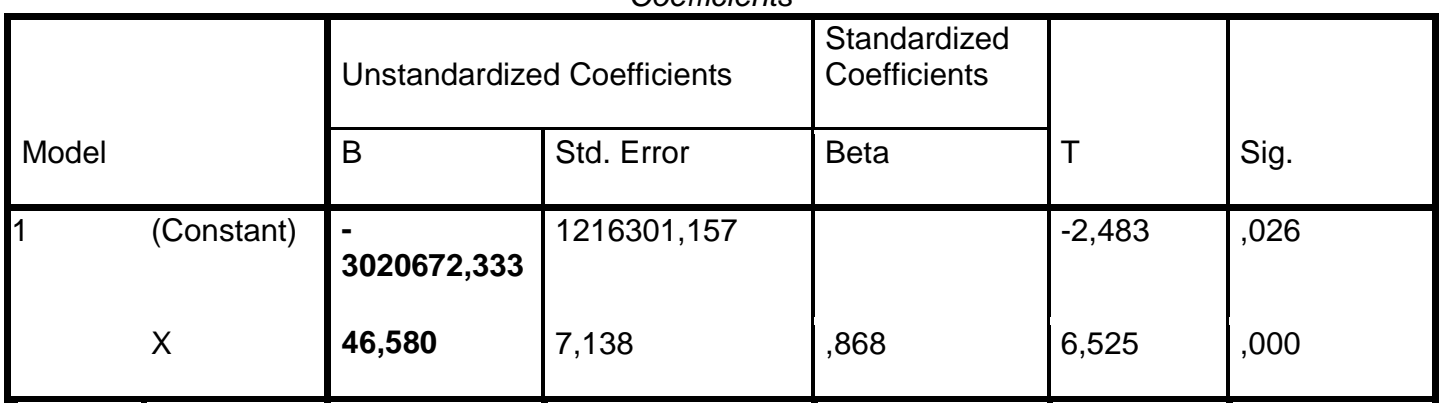

a. Dependent Variable: Y

According to the above table, it can be seen that the mathematical model that is formed is as follows:

\section{CONCLUSION}

Based on the above statistical calculations, it can be drawn a conclusion that is: During the reign

$$
\begin{aligned}
& Y=a+b X \\
& Y=-3.020 .672,33+46,580
\end{aligned}
$$

of the old Order and Reform Order of Foreign Debt has an influence on Indonesia's Economic Growth. Only in the reign of the New Order of 


\section{REFERENCES}

Atmadja, Adwin Surya. (2000). Utang Luar Negeri Indonesia : Perkembangan dan Dampaknya. Jurnal Akuntansi \& Keuangan Vol. 2, No. $\quad$ 1, $\quad \mathrm{Mei}$ http://puslit.petra.ac.id/journals/acc ounting.

Basri, Faisal. (2002). Perekonomian Indonesia : Tantangan dan Harapan Bagi Kebangkitan Indonesia. Penerbit Erlangga, Jakarta

Direktoral Jenderal Pengelolaan dan Pembiayaan Resiko. (2016). Kementerian keuangan Republik Indonesia. Avalaible http://www.djppr.kemenkeu.go.id

Fatmawati. Ria Yani. (2015). Analisis Pengaruh Perdagangan Internasional dan Utang Luar Negeri Terhadap Gross Domestic Product Indonesia (Periode 1990 2010). JESP-Vol. 7, No 1 Maret 2015 ISSN 2086-1575.

Ghozali, Imam, (2012). Aplikasi Analisis Multivariate Dengan Program SPSS.Badan Penerbit, Universitas Diponegoro, Semarang.

Malik, Abdul. Dan Denni Kurnia (2017) .Pengaruh Utang Luar Negeri dan Penanaman MODAL Asing Terhadap Pertumbuhan Ekonomi. Jurnal Akuntansi. Vol. 3 No. 2. Januari 2017 p-ISSN 2339-2436eISSN 2549-5968

Nizar, Chairul. (2013). Pengaruh Investasi dan Tenaga Kerja terhadap Pertumbuhan Ekonomi serta hubungannya terhadap Tingkat Kemiskinan di Indonesi. Jurnal Ilmu Ekonomi Universitas Syiah kuala. Http://www.academia.edu/8652807 /Jurnal_Ilmu_Ekonomi
_Pengaruh_Investas_Dan_Tenaga_ Kerja_Terhadap_Pertumbuhan_Eko nomi_Serta_Hubu ngannya_Terhadap_Tingkat_Kemis kinan_Di_Indonesia

Rahman, Aditya Bagus. (2017). Pengaruh Utang Luar Negeri dan Ekspor terhadap Pertumbuhan Ekonomi (Studi pada Produk Domestik Bruto Indonesia Periode 2005-2014) .Jurnal Adminitrasi Bisnis (JAB) Vol $4 . \quad$ No.1. administrasibisnis.studentjournal.ub .ac.id.

Rudi, Ishak. Mariska. (2017). PengaruhUutang Luar Negeri dan Penanaman Modal Asing terhadap Pertumbuhan Ekonomi Indonesia Periode Tahun 2009.3-2014.4. Jurnal Berkala Ilmiah Efisiensi. Volume 16 No. 02 Tahun 2016.

Sugiyono, (2012). Metode Penelitian Kuantitatif, Kualitatif dan $R \& D$, Penerbit ALFABETA : Bandung.

Sukirno, Sadono, (2012), Makro Ekonomi Pengantar. Edisi 3. Penerbit Rajawali Press. Jakarta

Tambunan,Hamongan,Tahi,Tulus. (2008) Pembangunan Ekonomi Dan Utang Luar Negeri. PT Raja Grafindo Persada. Jakarta

Tambunan,Hamongan,Tahi,Tulus. (2016) Perekonomian Indonesia: Era Orde Lama Hingga Jokowi.:PT Ghalia Indonesia. Jakarta

Todaro.MP. (2000). Pembangunan Ekonomi Dunia Ketiga. Erlangga. Jakarta

Trihendradi, C., (2009). SPSS 20 Step by Step Anlisis Data Statistik.: Penerbit ANDI. Yogyakarta

https://www.bps.go.id

https://www.bi.go.id 